\title{
Absence/hypoplasia of tibia, polydactyly, retrocerebellar arachnoid cyst, and other anomalies: an autosomal recessive disorder
}

Department of Newborn Medicine, Brigham and Women's Hospital, Boston, MA 02115, USA L B Holmes

Department of
Pathology,
Brigham and Women's
Hospital,
Boston,
MA 02115, USA
R W Redline
A J Williams
T Collins

Department of Radiology, Brigham and Women's Hospital, Boston, MA 02115, USA D L Brown

Correspondence to: Dr Holmes.

Received 3 April 1995 Revised version accepted for publication 19 June 1995

\section{Lewis B Holmes, Raymond W Redline, Douglas L Brown, Amy J Williams,} Tucker Collins

\begin{abstract}
Absence or hypoplasia of the tibia has been reported to occur as an isolated hereditary malformation as well as a feature of several autosomal recessive and autosomal dominant syndromes. We report three sibs with absence or hypoplasia of the tibia in association with other malformations whose parents are first cousins once removed. These infants appear to have a "new" autosomal recessive syndrome.
\end{abstract}

(F Med Genet 1995;32:896-900)

Absence or hypoplasia of the tibia is a rare congenital malformation which may occur as an isolated malformation or as part of a multiple malformation syndrome (table 1 ).${ }^{1-13}$ We report a family in which three affected sibs of related parents had a syndrome of multiple anomalies, including absence or hypoplasia of the tibia. The other anomalies include a variable pattern of pre- and postaxial polydactyly of the hands and feet, syndactyly of the toes, shortening of other long bones, and a cerebellar subarachnoid cyst. This phenotype appears different from those reported previously.

\section{Case reports}

The mother was interviewed before and after the birth of her second and third affected children. In none of her pregnancies was there an exposure to a known human teratogen. The family history showed that the parents are first cousins once removed. The mother had no skeletal malformations and reported none in her husband.

The first affected infant, a female, was born at term in the Dominican Republic (table 2). The mother was told by the physician who delivered this infant that she had a large head, unilateral cleft lip deformity, absence of the diaphragm, and short legs with the feet turned outwards and extra toes on the outer aspect of each foot. No records were available to confirm these findings.

The second affected infant, a male, was diagnosed by prenatal ultrasonography at 20 weeks of gestation as having a small $(1 \mathrm{~cm})$ cystic mass in the posterior fossa, a unilateral choroid plexus cyst, bowing of the radius and ulna and polydactyly of both arms, absence of the tibia, a club foot deformity, and polydactyly of both feet. The pregnancy was terminated electively after a prostaglandin infusion at 21 weeks of gestation. This fetus weighed $360 \mathrm{~g}$ (normal mean (1 SD) $353 \mathrm{~g}(125)$ ), ${ }^{14}$ had a head circumference of $19 \mathrm{~cm}$, crown-rump length of

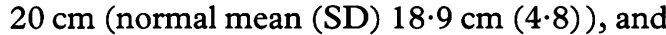
crown to heel length of $24.5 \mathrm{~cm}$ (normal mean (SD) $26 \cdot 2 \mathrm{~cm}(3 \cdot 6))$. The head appeared enlarged and had a hole $(1.5 \times 1.0 \mathrm{~cm})$ in the calvarium in the left occipital area. In association with a visible bulge in the occipital region (fig 1), there was a multiloculated $(1.5 \times 1.0 \mathrm{~cm})$ retrocerebellar subarachnoid cyst in the posterior fossa and a normal cerebellar vermis, which excluded the diagnosis of a Dandy-Walker cyst. There was no cleft lip or palate deformity. The facial features included a prominent bridge of the nose, maxillary hypoplasia, and small chin. The diaphragm was intact. There was a long mesentery with a partial malrotation of the large bowel. There was a single extra digit on the ulnar aspect of each hand (fig 1), but no syndactyly. The distance between the knees and ankles appeared shortened. An extra well formed toe was present on the inner aspect of the left foot; there was no syndactyly. The right foot showed an enlarged fifth toe with duplication of the fifth toenail and syndactyly between the fourth and fifth toes.

Postmortem radiographs showed absence of the tibia and a bowed fibula (fig 2). There was no synostosis of the tarsals, the ankle bones were ossified, but the possibility of synostosis could not be ruled out. There was no apparent shortening of the radii. The extra digit was associated with an extra metacarpal in the

\section{Table 1 Phenotypes that include absent tibia}

\section{Autosomal recessive}

(1) Isolated absence of the tibia ${ }^{8}$

2) Tibia hemimelia, bifid femur, and split hand $/$ foot $^{3}$

3) Tibia hemimelia and deafness

4) Tibia hemimelia and cleft lip/palate ${ }^{10}$

Autosomal dominant

(1) Isolated absence of the tibia

(2) Aplasia of tibia and preaxial polydactyly or absent thumb ${ }^{4}$

(3) Tibia hemimelia and split hand/foot ${ }^{9}$

(4) Tibia hemimelia and duplication of ulna and fibula

(5) Tibia hemimelia, shortened limbs, and trigonomacrocephaly

(6) Absence of tibia and radius ${ }^{6}$

(7) Sandrow's syndrome of duplication of hands and feet, nose defect, and tibia hypoplasia

(8) Hypoplastic tibiae with postaxial polysyndactyly ${ }^{11} 12$ 
Table 2 Phenotypes

\begin{tabular}{llll}
\hline Features & $\begin{array}{l}\text { Case 1 } \\
\text { (female) }\end{array}$ & $\begin{array}{l}\text { Case 2 } \\
\text { (male) }\end{array}$ & $\begin{array}{l}\text { Case 3 } \\
\text { (male) }\end{array}$ \\
\hline Retrocerebellar (arachnoid cyst) & $\begin{array}{l}\text { "Fluid on brain" } \\
\text { (by history) }\end{array}$ & + & + \\
Ventriculomegaly & $?$ & + & + \\
Cleft lip & + & - & - \\
$\begin{array}{l}\text { Diaphragmatic agenesis } \\
\text { Malrotation of colon }\end{array}$ & + & + & $?$ \\
Radius shortened & $?$ & + & + \\
Tibia hypoplasia/absence & $?$ & + & + \\
$\begin{array}{l}\text { Polydactyly } \\
\text { Hands (postaxial) }\end{array}$ & + & + & - \\
$\quad$ Feet & + & - & + \\
Syndactyly of toes 4-5 & + & + & (Pre) \\
\hline
\end{tabular}

hands and with an extra metatarsal in the feet. Chromosome studies on amniocytes with Giemsa, Dappi, and Methyl $A_{3}$ stained metaphases showed a normal 46,XY karyotype.

The third pregnancy was monitored by prenatal ultrasonography, which suggested by 12 weeks of gestation that the fetus had a club foot deformity. Prenatal ultrasonography at 19 weeks of gestation identified dilated lateral cerebral ventricles, a retrocerebellar cyst (fig 3 ), shortening of the tibiae, and polydactyly of the feet. After an elective termination by a destructive procedure, the neuropathology and status of the diaphragm, heart, intestine, liver, spleen, and gonads could not be assessed. There was no cleft palate or polydactyly of either hand. There was preaxial polydactyly of both feet (fig 4), medial rotation of the feet, and shortened tibiae. Radiographs showed shortened and broad tibiae and fibulae and widening of the metaphyses of both femora. Chromosome studies with Giemsa and $\mathrm{CA}_{3} \mathrm{DA}$

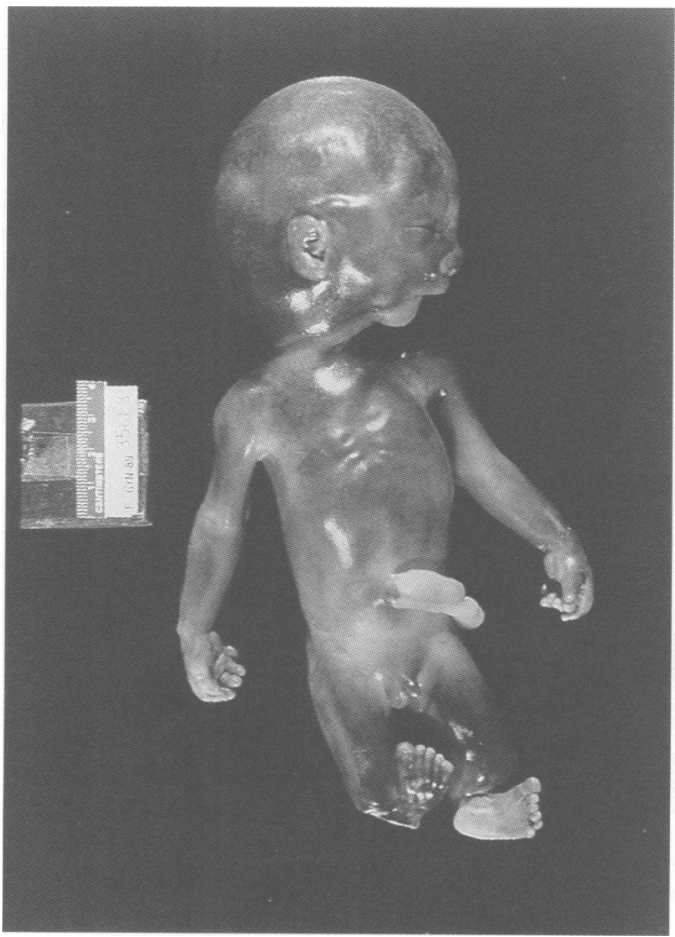

Figure 1 A picture of fetus 2 which shows the prominent occiput, small chin, postaxial polydactyly of the hands and feet, and shortened lower leg with positional foot deformity.

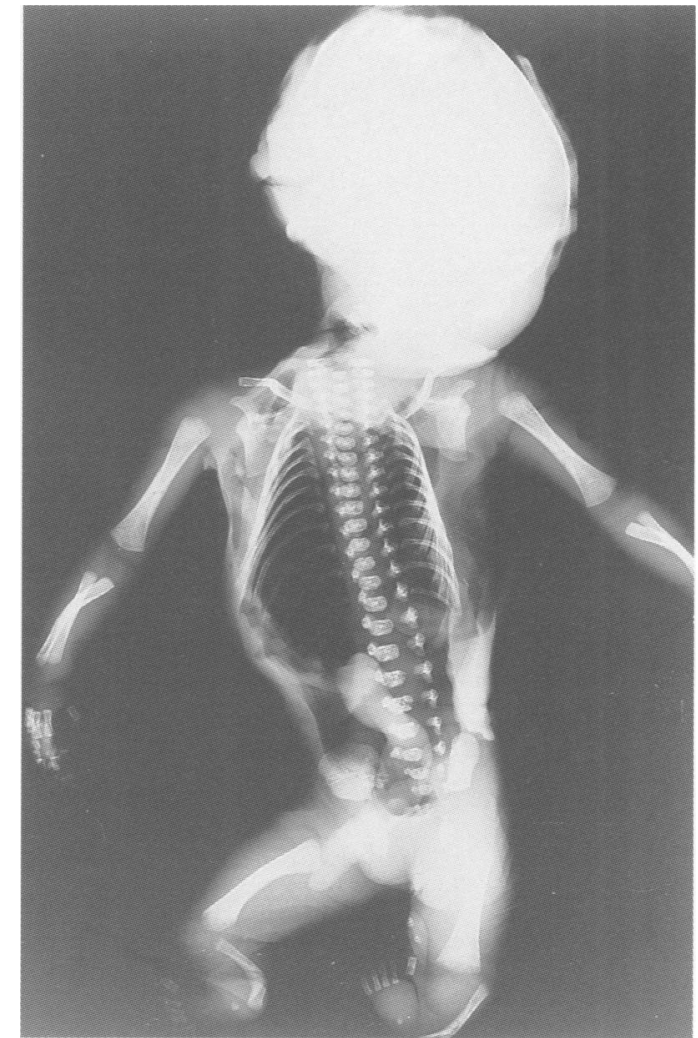

Figure 2 The postmortem radiograph of fetus 2 which shows complete absence of the tibia and a bowed fibula.

banding of seven metaphases showed a normal $46, \mathrm{XY}$ karyotype; 24 metaphases were counted.

Subsequently, this couple has had two normal pregnancies. These were followed by prenatal sonography with no abnormalities identified and normal infants were born at term.

HOX genes of several different classes have been implicated in limb development. As part of a larger survey of infants with multiple malformations, we performed Southern blot analysis using probes for several HOX genes, looking for structural arrangements. DNA was obtained from infants 2 and 3, the mother, and the father. A total of $10 \mu \mathrm{g}$ was digested with restriction enzymes, screened by Southern blot analysis and probed with $\mathrm{CDNA}$ clones for the HOXD10, C9, and A9 genes. ${ }^{15-17} \mathrm{An}$ anomalous band of $4.5 \mathrm{~kb}$ was identified in HindIII digested DNA from infant 2 when probed with the HOXD10 cDNA. HOXC9 and HOXA9 restriction patterns were identical to all other fetuses tested in the survey (data not shown). No anomalous HOXD10 band was found in DNA from infant 3, the mother, or the father. Additionally, this band was not seen in samples from 25 other infants with multiple malformations or in normal adults.

\section{Discussion}

In a review of the phenotypes of malformation syndromes associated with absence or hypoplasia of the tibia (table 1), we could identify 

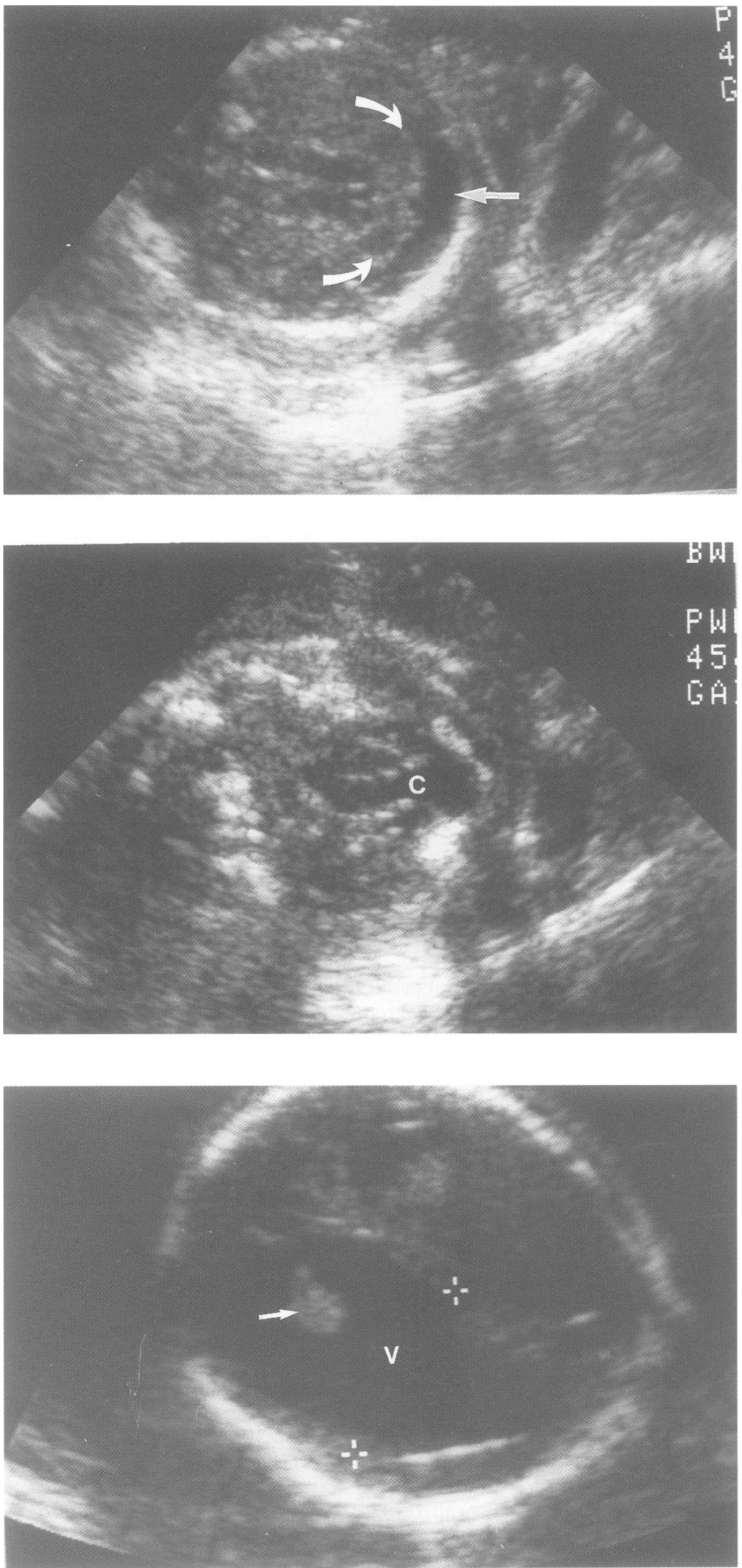

Figure 3 Three images of the intracranial structures in the third affected pregnancy. (Top) Transverse view of the posterior fossa at 19 weeks shows slightly small cerebellum (between curved arrows). The cisterna magna (straight arrow) measured $6 \mathrm{~mm}$ in anteroposterior diameter which is normal. (Middle) Image slightly more inferior and oblique compared to above shows elongated cyst (labelled " $C$ ") in the posterior fossa. Prenatally, this suggested either a Dandy-Walker variant or an arachnoid cyst. The sonographic appearance of this cyst was identical to that seen in the second affected fetus. (Bottom) Transverse image more superiorly shows dilatation of one of the lateral ventricles (labelled " $V$ "). The lateral ventricle in the upper half of the calvarium is not as well seen owing to noise but was also dilated. Choroid plexus (arrow) is seen in the dilated ventricle.

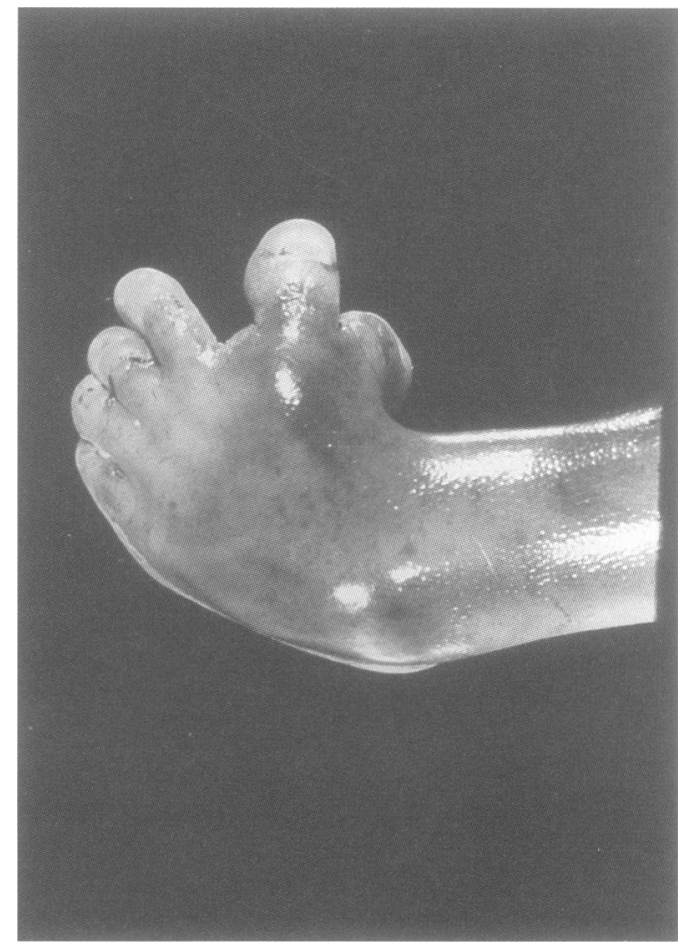

Figure 4 Preaxial polydactyly of the feet of fetus 3.

none just like the three sibs we report. Since their parents are unaffected and are related, it is most likely that this disorder is the result of a rare autosomal recessive gene. We did identify two phenotypes which showed some similarity. First, Burn et $a l^{18}$ reported two sisters who were considered to have orofaciodigital syndrome with tibial dysplasia and had been born to parents who were first cousins. Their facial features included a broad and flattened nasal bridge, cleft palate in one, micrognathia, and hamartomas of the tongue. Their skeletal abnormalities included pre- and postaxial polysyndactyly, proximal shortening of the tibia with a generalised mesomelia, and shortened and poorly ossified bones in the middle phalanges. Both girls were delayed developmentally, had a bilateral conductive hearing loss, and had oculomotor apraxia. A CT scan of the head showed mild cerebral atrophy in one sister, but not in the other. Burn et $a l^{18}$ noted that two other sets of similarly affected sibs have been reported with mesomelic shortening of all limbs and flared metaphyses. Our patients differ in having retrocerebellar arachnoid cysts, having no hamartomas of the tongue in the one infant examined carefully (case 2), and no general mesomelia. It is particularly important to note that these children had proximal shortening of the tibia, whereas the shortening was distal in our patients. Secondly, Al-Awadi et $a l^{11}$ and Naguib and Al-Awadi ${ }^{12}$ reported a brother and sister with hypoplasia of the tibia, syndactyly of toes $2-3$, and postaxial polysyndactyly of both hands. Their parents were related; the mother had syndactyly, the father had polydactyly, and a sister had polysyndactyly, raising 
the possibility that the affected sibs were homozygous for a dominant gene. The family we report differs in that neither parent had a limb malformation and in the other malformations present.

The potential causes of absence or hypoplasia of the tibia could include errors in several different aspects of limb development. For example, cells from the primitive streak have been shown to migrate to the lateral plate mesoderm. ${ }^{19}$ An abnormality of this process could affect the limb bud which forms from the mesenchyme cells in the lateral plate mesoderm. By using coils placed between the somites and the early chick limb bud, Stephens et $a l^{2021}$ have shown that both Hensen's node and the adjacent axial (somite) structures affect early chick limb morphogenesis between stages 11 and 15. They showed that the limb was induced by several different somites; their findings suggest that a deficiency of one portion of a long bone could be the result of the lack of an influence from specific somites.

Vertebrate HOX genes at the $5^{\prime}$ end of the $A$ and $D$ clusters are activated sequentially over two to three days during the development of the limb. ${ }^{223}$ The fact that HOX gene expression in the mouse closely parallels the expression in humans ${ }^{1516}$ made it logical to use available HOXA9 and HOXD10 probes, as well as a third HOX gene (HOXC9), to search for structural abnormalities in these regions using DNA from the affected fetuses. While our initial finding of an abnormal restriction fragment in the HOXD10 region of affected fetus 2 was intriguing, subsequent analysis of DNA from the similarly affected sib (fetus 3) showed a normal restriction pattern. Therefore, we have no evidence that any of these three genes are involved in this syndrome.

Abnormalities in the transcription factors, such as $\mathrm{HOX}, \operatorname{Pax}-1$, and $\mathrm{Msx}-1$, and zinc finger proteins have been associated with malformations of the developing axial spine and limb. Mutations in these genes are examples of the types of primary abnormality that could produce the hereditary disorder we report. For example, disruption of the HOXd-13 gene in the mouse produced several abnormalities, including fusion of sacral vertebrae 3 and 4 , reduction in the size or absence of digits, and postaxial polydactyly in the forelimbs. ${ }^{24}$ Mice homozygous for undulated $^{\text {severe }}$ have a point mutation in the homeobox gene in PAX-1, in association with multiple vertebral and rib anomalies. ${ }^{25}$ Deletions in the GLI-3 gene, a zinc finger protein, occur in the Greig cephalopolysyndactyly syndrome ${ }^{26}$ in which affected subjects have craniofacial abnormalities, occasionally hydrocephalus, and preaxial polysyndactyly of the hands and feet. The mechanism by which deletions in the GLI3 gene causes these malformations is not known; this gene is expressed normally in the interdigital space, as well as craniofacial nonlimb structures and brain. ${ }^{27} \mathrm{Msx}-1$ is expressed at sites where epithelial mesenchymal interactions are occurring and its expression is diminished in embryos homozygous for limbless. $^{28}$
We have confirmed in prenatal screening that the malformations of the lower legs in fetuses 2 and 3 could be detected as early as 12 menstrual weeks. This was suspected because of the presence of the appearance of a "club foot" deformity, as was the case in the 16.5 week fetus with absence of the tibia reported by Ramirez et al. $^{29}$

In summary, we have described a new constellation of anomalies characterised by tibial anomalies, polydactyly, and a large retrocerebellar arachnoid cyst which appears to have an autosomal recessive inheritance pattern.

We thank Janice Stryker for her invaluable assistance in obtaining lood samples from the parents in this family. This work was supported in part by funds from the New England Regional Genetics Group, the Peabody Foundation Inc, Boston, and by NIH Grants KO8-HD-00864 and RO1-HL-45462. TC is an Established Investigator of the American Heart Association.

1 Carraro A. Assenza congenita delle tibia e sordomutismo nel quattro fratelli. Chir Organi Mov 1931;16:429-38.

2 Laurin CA, Favreau JC, Labelle P. Bilateral absence of the radius and tibia with bilateral reduplication of the uln and fibula. F Bone foint Surg (Am) 1964;46:137-42.

3 Takahashi T, Yamamoto $M$, Mochizuki Y. Four cases of bilateral splithand with bilateral aplasia of the tibia in a family. Orthop Surg (Tokyo) 1968;19:95-8.

4 Pashayan H, Fraser FC, McIntyre JM, Dunbar JS. Bilateral aplasia of the tibia, polydactyly and absent thumb in father aplasia of the tibia, polydactyly and absent thumb in father

5 Clark MW. Autosomal dominant inheritance of tibia meromelia. Report of a kindred. $\mathcal{F}$ Bone foint Surg ( $\mathrm{Am}$ ) 1975; 57:262-4.

6 Temtamy SA, McKusick VM. The genetics of hand malformations. Birth Defects: Original Article Series, XIV(3). The National Foundation - March of Dimes. New York Alan R Liss, 1978

7 Wiedemann HR, Opitz JM. Unilateral partial tibia defect with preaxial polydactyly, general micromelia and trigonomacrocephaly with a note on "developmental resistance". Am F Med Genet 1983;14:467-72.

8 McKay M, Clarren SK, Zorn R. Isolated tibia hemimelia in sibs: an autosomal-recessive disorder? $A m \mathcal{F}$ Med Genet 1984;17:603-7.

9 Majewski F. Küster W, ter Haar B, Goecke T. Aplasia of tibia with split-hand/split-foot deformity. Report of six families with 35 cases and considerations about variability families with 35 cases and considerations about

10 Richieri-Costa A. Tibial hemimelia-cleft lip/palate in a Brazilian child born to consanguineous parents. Am $\mathscr{f} \mathrm{Med}$ Genet 1987;28:325-9.

11 Al-Awadi SA, Naguib KK, Farag TI, Teebi AS. Hypoplastic tibiae with postaxial polysyndactyly: a new semidominant syndrome. $\mathcal{f}$ Med Genet 1987;24:369-72.

12 Naguib KK, Al-Awadi SA. Hypoplastic tibiae with postaxial polysyndactyly in two sibs. Further confirmation of a new syndrome. Am $\mathcal{F}$ Med Genet 1990;35:588-9.

13 Martin RA, Jones MC, Jones KL. Mirror hands and fee with a distinct nasal defect, an autosomal dominant condition. Am ₹ Med Genet 1993;46:129-31.

14 Singer DB, Sung CJ, Wigglesworth JS. Fetal growth and maturation: with standards for body and organ development. In: Wigglesworth JS, Singer JB, eds. Textbook of fetal and perinatal pathology. Boston: Blackwell Scientific Publications, 1991:11-48.

15 Redline RW, Neish A, Holmes LB, Collins T. Homeobox genes and congenital malformations. Lab Invest 1992;66: 659-70.

16 Redline RW, Williams A, Patterson P, Collins T. Human HOX 4E: a gene strongly expressed in the adult male and HOX 4E: a gene strongly expressed in the adult male

17 Redline RW, Hudock P, MacFee M, Patterson P. Expression of AbdB-type homeobox genes in human tumors. Lab of AbdB-type homeobox

18 Burn J, Dezateux C, Hall CM, Baraitser M. Oro-faciodigital syndrome with mesomelic limb shortening. $\mathcal{F} \mathrm{Med}$ Genet 1984;21:189-92.

19 Inagaki T, Garcia-Martinez V, Schoenwolf GC. Regulative ability of the prospective cardiogenic and vasculogenic areas of the primitive streak during avian gastrulation. Developmental Dynamics 1993;197:57-68.

20 Stephens TD, McNulty TR. Evidence for a metameric pattern in the development of the chick humerus. $\mathcal{F}$ Embryol Exp Morphol 1981;61:191-205.

21 Stephens TD, Roberts SG, Marchiando RJ, et al. Axial and paraxial influences on the origin of the chick embryo limb. In: Fallon JF, Goetinck PF, Kelley RO, Stocum DL, eds. Limb development and regeneration. Part A. New York: Wiley-Liss, 1993:317-26. 
22 Dollé $\mathrm{P}$, Izpisúa-Belmonte J-C, Falkenstein $\mathrm{H}$, Renucci A, Duboule DL. Coordinate expression of the murine HOX5 complex homeobox-containing genes during limb pattern foundation. Nature 1989;342:767-74.

23 Yokouchi Y, Sasaki H, Kuroiwa A. Homeobox gene expression correlated with the process of limb cartilage development. Nature 1991;353:443-5.

24 Dolle $\mathrm{P}$, Dierich A, LeMeur M, et al. Disruption of the HOXd-13 gene induces localized heterochrony leading to mice with neotenic limbs. Cell 1993;75:413-41.

25 Balling R, Deutsch U, Gruss P. Undulated, a mutation affecting the development of the mouse skeleton, has a point mutation in the paired box of Pax 1. Cell 1988;55: 531-5.
26 Vortkamp A, Gessler M, Grzeschik KH. GL13 zinc-finger gene interrupted by translocations in Greig syndrome families. Nature 1991;352:539-40.

27 Hui CC, Joyner AL. A mouse model of Greig cephalopolysyndactyly syndrome: the extra-toes ${ }^{\mathrm{S}}$ mutation contains an syndactyly syndrome: the extra-toes mutation contains an 3:241-6.

28 Brown JM, Wedden SE, Millburn HG, et al. Experimental analysis of the control of expression of the homeoboxgene Msx-1 in the developing limb and face. Development 1993;119:41-8.

29 Ramirez M, Hecht JT, Taylor S, Williams I. Tibial hemimelia syndrome: prenatal diagnosis by real-time ultrasound. Prenat Diagn 1994;14:167-71. 